\title{
Орфанні захворювання в ендокринології
}

\section{М.Д. Тронько, А.М. Кваченюк, Л.А. Луценко, I.C. Супрун, 0.0. Охрімчук}

ДУ «Інститут ендокринології та обміну речовин ім. В.П. Комісаренка НАМН України»

\begin{abstract}
Резюме. Медико-соціальне значення ендокринних орфанних захворювань обумовлено труднощами в діагностиці та лікуванні, а також несприятливим прогнозом і високою частотою інвалідизації пацієнтів із цією патологією. Особливо це стосується таких захворювань, як акромегалія та множинна ендокринна неоплазія. В Європі існує спеціальна програма, яка направлена на вирішення різноманітних питань щодо діагностики, лікування та соціального забезпечення пацієнтів з орфанними захворюваннями. Європейський проект «Орфанет» підтримується державними структурами, об'єднує інформацію щодо рідкісних захворювань практично у всіх європейських країнах і включає європейські, інтернаціональні, національні та регіональні реєстри орфанних захворювань. В Україні опубліковано Наказ Міністерства охорони здоров'я (МО3) України від 27.10.2014 р. № 778 «Про затвердження переліку рідкісних (орфанних) захворювань», яким офіційно затверджено 302 нозології, що віднесені до рідкісних захворювань. Серед орфанних захворювань вказано 61 рідкісну ендокринну хворобу (зокрема, розлади харчування та порушення обміну речовин), а також природжені вади розвитку, хромосомні аномалії та рідкісні новоутворення, у визначенні тактики ведення яких лікар-ендокринолог бере безпосередню участь. Останнім часом зростає частота виявлення орфанних захворювань, зокрема і ендокринних. Причиною цього може бути покращення методів інструментальної та лабораторної діагностики, використання генетичних методів діагностики та більш широка обізнаність лікарів різних спеціальностей щодо ранніх проявів орфанних захворювань. В Україні проблема орфанних захворювань тривалий час перебувала в інертному стані. Ініціація ухвалення Національної стратегії з профілактики, діагностики та лікування рідкісних (орфанних) захворювань в Україні свідчить про визнання проблеми на державному рівні та дає можливість вирішення питань своєчасного виявлення і лікування рідкісних захворювань, а також забезпечення пацієнтів життєво необхідними лікарськими засобами.
\end{abstract}

Ключові слова: ендокринні орфанні захворювання, акромегалія, множинна ендокринна неоплазія.

У 1983 р. в США було прийнято законодавчий акт «Orphan Drug Act», завдяки якому вперше прозвучав термін «орфанні хвороби» та визначено 1600 рідкісних хвороб невідомої етіології. Орфанними (від англійського

\footnotetext{
* Адреса для листування (Correspondence): ДУ «Інститут ендокринології та обміну речовин ім. В.П. Комісаренка НАМН України», вул. Вишгородська, 69, м. Київ, 04114, Україна. E-mail: Lucenko_L_A@ukr.net
}

๑ М.Д. Тронько, А.М. Кваченюк, Л.А. Лученко, І.С. Супрун, О.О. Охрімчук «orphan» - сирота, сирітський) названо захворювання, частота поширення яких не перевищує один випадок на 2000 населення. На теперішній час Європейським комітетом експертів із рідкісних захворювань зареєстровано до 8000 різних рідкісних захворювань, із них лише 250 орфанних захворювань мають свій шифр у Міжнародній класифікації хвороб. 
Огляди

Вважається, що показник поширеності орфанних захворювань не є уніфікованим. У різних країнах/регіонах критерії «орфанності» захворювання відрізняються і їх частота може коливатися. Рівень розповсюдженості цих патологій може бути низьким в одному регіоні (чи популяціï) та високим в іншому. Згідно даних офіційного веб-сайту Європейського Союзу в Європі будь-яке захворювання, що вражає менше 5 осіб на 10000 , вважається рідкісним [1]. У більшості ж випадків захворювання вважаються орфанними, коли вражає 1 людину на 100000 і більше. У країнах Свропейського Союзу на рідкісні захворювання страждає 6-8\% населення, тобто від 27 до 36 мільйонів людей [1]. Розрахункова поширеність орфанних ендокринних захворювань коливається від 0,08 до 64 випадків на 100000 осіб [2] (табл. 1).

Вік маніфестації орфанних захворювань може бути різним, більшість із них діагностують у ранньому віці. Враховуючи труднощі в діагностиці, встановлення правильного діагнозу може бути відтерміновано.

Близько 80\% рідкісних захворювань є результатом генних та хромосомних мутацій, інші зумовлені мікроорганізмами (вірусами, бактеріями), алергічними агентами або факторами зовнішнього середовища. Для багатьох орфанних захворювань характерна поліорганна ураженість, яка потребує кваліфікованої допомоги лікарів різних спеціальностей.

Таким чином, труднощі в діагностиці, дороговартісне, специфічне та часто пожиттєве лікування, несприятливий прогноз, висока частота інвалідизації пацієнтів зумовлюють медико-соціальне значення орфанних захворювань.

За підтримки Європейського Союзу в Європі існує спеціальна програма, яка спрямована на вирішення різноманітних питань щодо діагностики, лікування та соціального забезпечення пацієнтів з орфанними захворюваннями. У 1997 р. Французьким національним інститутом охорони здоров'я та медичних досліджень (French National Institute for Health and Medical Research) було створено проект «Орфанет» (www.orpha.net). На сьогодні це консорціум із 40 країн, який об'єднує інформацію щодо орфанних захворювань практично у всіх країнах Свропи. Згідно даних звіту проекту «Орфанет», який опубліковано в травні
2019 р., загальна кількість реєстрів захворювань становила: 60 європейських, 80 регіональних, 58 інтернаціональних та 535 національних. Один реєстр існує в Україні - це реєстр пацієнтів зі спинальною м'язовою атрофією [2].

15.04 .2014 р. прийнято Закон України № 1213-VII «Про внесення змін до Основ законодавства України про охорону здоров'я щодо забезпечення профілактики та лікування рідкісних (орфанних) захворювань», яким визначено поняття «рідкісне (орфанне) захворювання» - це захворювання, яке загрожує життю людини або яке хронічно прогресує, призводить до скорочення тривалості життя громадянина або до його інвалідності, поширеність якого серед населення не частіше ніж $1: 2000 \gg[3]$.

27.10.2014 р. опубліковано Наказ МОЗ України № 778 «Про затвердження переліку рідкісних (орфанних) захворювань» (зі змінами, внесеними згідно з Наказами МОЗ України № 919 від 30.12.2015 р., № 731 від 29.06.2017 р. і № 2664 від 24.12.2019 р.). У переліку вказано орфанні захворювання, що призводять до скорочення тривалості життя пацієнтів або їх інвалідизації та для яких існують визнані методи лікування. Таким чином, в Україні офіційно затверджено 302 нозології, які віднесено до рідкісних захворювань [4]. Серед орфанних захворювань вказано 61 рідкісну ендокринну хворобу (зокрема, розлади харчування та порушення обміну речовин), а також природжені вади розвитку, хромосомні аномалії та рідкісні новоутворення, у визначенні тактики ведення яких ендокринолог бере безпосередню участь [5] (табл. 2).

Деякі орфанні захворювання досить часто зустрічаються в практиці ендокринолога. Наприклад, частота виявлення пролактиноми в багатьох країнах Свропейського Союзу складає 1/1600 осіб. Захворюванням страждають переважно жінки, особливо пременопаузального віку. Пролактинома складає 66\% клінічно значущих випадків аденоми гіпофізу [6]. Лабораторні та інструментальні методи діагностики дають можливість встановити діагноз пролактиноми, провести диференційну діагностику, а наявність препаратів агоністів дофаміну - призначити коректне лікування.

У випадках підозри інших орфанних захворювань ситуація може бути інакшою. Наприклад, діагностика акромегалії не викликає 
Таблиця 1. Розрахункова поширеність орфанних ендокринних захворювань

Table 1. Estimated prevalence of orphan endocrine diseases

\begin{tabular}{|c|c|c|c|c|c|}
\hline $\begin{array}{l}\text { ORPHA } \\
\text { HOMEP } \\
\text { ORPHA } \\
\text { number }\end{array}$ & $\begin{array}{l}\text { Захворювання або група } \\
\text { захворювань } \\
\text { Disease or group of diseases }\end{array}$ & $\begin{array}{l}\text { Розрахункова } \\
\text { поширеність/ } \\
\text { захворюваність } \\
\text { [Estimated } \\
\text { prevalence / } \\
\text { incidence] } \\
\text { (/100 000) }\end{array}$ & $\begin{array}{l}\text { ORPHA } \\
\text { нOMep } \\
\text { ORPHA } \\
\text { number }\end{array}$ & $\begin{array}{l}\text { Захворювання або група } \\
\text { захворювань } \\
\text { Disease or group of diseases }\end{array}$ & $\begin{array}{l}\text { Розрахункова } \\
\text { поширеність/ } \\
\text { захворюваність } \\
\text { [Estimated } \\
\text { prevalence / } \\
\text { incidence] } \\
(/ 100000)\end{array}$ \\
\hline 963 & $\begin{array}{l}\text { Акромегалія } \\
\text { Acromegaly }\end{array}$ & $0.47 \mid$ & 1332 & $\begin{array}{l}\text { Медулярна карцинома } \\
\text { щитоподібної залози }\end{array}$ & $5.0 P^{*}$ \\
\hline 99892 & $\begin{array}{l}\text { АКТГ-залежний синдром Кушинга } \\
\text { АСТН-dependent Cushing } \\
\text { syndrome }\end{array}$ & 0.551 & 1332 & $\begin{array}{l}\text { Medullary thyroid carcinoma } \\
\text { Медулярна карцинома } \\
\text { щитоподібної залози }\end{array}$ & $0.221 *$ \\
\hline 85138 & $\begin{array}{l}\text { Хвороба Аддісона } \\
\text { Addison disease }\end{array}$ & $12.5 P *$ & 652 & $\begin{array}{l}\text { Medullary thyroid carcinoma } \\
\text { Множинна ендокринна }\end{array}$ & $3.3 P *$ \\
\hline 1501 & $\begin{array}{l}\text { Адренокортикальна карцинома } \\
\text { Adrenocortical carcinoma }\end{array}$ & $0.75 P^{*}$ & & $\begin{array}{l}\text { неоплазія, тип } 1 \\
\text { Multiple endocrine neoplasia type } 1\end{array}$ & \\
\hline 1501 & $\begin{array}{l}\text { Адренокортикальна карцинома } \\
\text { Adrenocortical carcinoma }\end{array}$ & $0.03 I^{*}$ & 653 & $\begin{array}{l}\text { Множинна ендокринна } \\
\text { неоплазія, тип } 2\end{array}$ & $2.9 P *$ \\
\hline 418 & $\begin{array}{l}\text { Вроджена наднирникова } \\
\text { гіперплазія } \\
\text { Congenital adrenal hyperplasia }\end{array}$ & $10.0 P *$ & 877 & $\begin{array}{l}\text { Multiple endocrine neoplasia type } 2 \\
\text { Нейроендокринне утворення } \\
\text { Neuroendocrine neoplasm }\end{array}$ & $2.53 I^{*}$ \\
\hline 418 & $\begin{array}{l}\text { Вроджена наднирникова } \\
\text { гіперплазія } \\
\text { Congenital adrenal hyperplasia }\end{array}$ & $6.7 \mathrm{BP} *$ & 97253 & $\begin{array}{l}\text { Нейроендокринна пухлина } \\
\text { підшлункової залози } \\
\text { Neuroendocrine tumor of pancreas }\end{array}$ & $0.211^{*}$ \\
\hline 418 & $\begin{array}{l}\text { Вроджена наднирникова } \\
\text { гіперплазія } \\
\text { Congenital adrenal hyperplasia }\end{array}$ & $13.35 I^{*}$ & $\begin{array}{l}2965 \\
314769\end{array}$ & $\begin{array}{l}\text { Пролактинома } \\
\text { Prolactinoma } \\
\text { Соматопролактинома }\end{array}$ & \\
\hline 54595 & $\begin{array}{l}\text { Краніофарінгеома } \\
\text { Craniopharyngioma }\end{array}$ & $2.0 P^{*}$ & 97283 & $\begin{array}{l}\text { Somatoprolactinoma } \\
\text { Соматостатинома }\end{array}$ & $0.0025 I^{*}$ \\
\hline 54595 & $\begin{array}{l}\text { Краніофарінгеома } \\
\text { Craniopharyngioma }\end{array}$ & 1.01 & 100088 & $\begin{array}{l}\text { Somatostatinoma } \\
\text { Карцинома щитоподібної залози }\end{array}$ & $12.7 P$ \\
\hline 96253 & $\begin{array}{l}\text { Хвороба Кушинга } \\
\text { Cushing disease }\end{array}$ & $4.0 P *$ & 100088 & $\begin{array}{l}\text { Thyroid carcinoma } \\
\text { Карцинома щитоподібної залози }\end{array}$ & 3.11 \\
\hline 96253 & $\begin{array}{l}\text { Хвороба Кушинга } \\
\text { Cushing disease }\end{array}$ & $0.2 I^{*}$ & 95712 & $\begin{array}{l}\text { Thyroid carcinoma } \\
\text { Ектопія щитоподібної залози }\end{array}$ & $14.3 P *$ \\
\hline 553 & $\begin{array}{l}\text { Синдром Кушинга } \\
\text { Cushing syndrome }\end{array}$ & $5.9 P$ & 95720 & $\begin{array}{l}\text { Thyroid ectopia } \\
\text { Гіпоплазія щитоподібної залози }\end{array}$ & $3.5 P$ \\
\hline 553 & $\begin{array}{l}\text { Синдром Кушинга } \\
\text { Cushing syndrome }\end{array}$ & $0.15 I^{*}$ & 100087 & $\begin{array}{l}\text { Thyroid hypoplasia } \\
\text { Пухлина щитоподібної залози }\end{array}$ & 3.21 \\
\hline 189427 & $\begin{array}{l}\text { Синдром Кушинга внаслідок } \\
\text { макронодулярної гіперплазії } \\
\text { надниркових залоз }\end{array}$ & $0.08 P^{*}$ & 182130 & $\begin{array}{l}\text { Thyroid tumor } \\
\text { Пухлина ендокринних залоз } \\
\text { Tumor of endocrine glands }\end{array}$ & $64.0 P *$ \\
\hline & $\begin{array}{l}\text { Cushing syndrome due to } \\
\text { macronodular adrenal hyperplasia }\end{array}$ & & 182130 & $\begin{array}{l}\text { Пухлина ендокринних залоз } \\
\text { Tumor of endocrine glands }\end{array}$ & $3.751 *$ \\
\hline
\end{tabular}

Примітка: * - європейські дані, $P$ - поширеність, I-захворюваність, ВP-поширеність у новонароджених Note: * European data, $P$ - prevalence, I - incidence, $B P$ - prevalence in newborns.

великих труднощів на момент появи клінічних проявів. Лабораторні методики визначення інсуліноподібного фактора росту-1 (IФP-1), соматотропного гормону (СТГ) дозволяють діагностувати гіперсоматотропінемію, а магнітно-резонансна томографія (МРТ) гіпофізу виявити соматотропіному [7].
На цей час в Україні офіційно зареєстровано 844 пацієнти з акромегалією, хоча розрахункова кількість пацієнтів з акромегалією в Україні може сягати приблизно 2500. Більш точну цифру поширеності акромегалії спрогнозувати складно, до того ж, невідома кількість пацієнтів із недіагностованою 
Огляди

таблиця 2. Перелік найбільш поширених орфанних захворювань, які зареєстровані в Україні та потребують ендокринологічної допомоги [4]

Table 2. List of the most common orphan diseases that are registered in Ukraine and need endocrinological care [4]

Нозологія
Nosology

Гіперінсулінізм

E16.1

Hyperinsulinism

Псевдогіпопаратиреоз

E20.1

Pseudohypoparathyroidism

Гіпопаратиреоз, інші форми гіпопаратиреозу

E20.8

Hypoparathyroidism, other forms of

hypoparathyroidism

Акромегалія і гіпофізарний гігантизм

Acromegaly and pituitary gigantism

Передчасне статеве дозрівання центрального

походження

Central precocious puberty

Гіпопітуїтаризм

Hypopituitarism

Діабет нецукровий

Diabetes insipidus

Хвороба (Іценка -) Кушинга гіпофізарного

походження

Cushing's disease

Ектопічний АКТГ синдром

Ectopic ACTH syndrome

Природжені адреногенітальні порушення,

пов'язані з ферментною недостатністю

Congenital adrenogenital disorders associated with enzyme deficiency

Первинна недостатність кіркової речовини

надниркових залоз,

Primary adrenal insufficiency

Адреналовий криз

Adrenal crisis

Гіпофункція яєчок,

Male hypogonadism

Синдром андрогенної резистентності,

тестикулярна фемінізація (синдром)

Androgen insensitivity (testicular feminization)

syndrome

Передчасне статеве дозрівання

Precocious puberty

Автоімунна полігландулярна недостатність

(автоімунний полігландулярний синдром, тип I)

Autoimmune polyglandular insufficiency

(Autoimmune polyglandular syndrome type 1)

E22.0

E22.8

E23.0

E 24.0

E 24.3

E25.0

E27.1,

E27.2

E29.1,

E34.5

E30.1

E31.0

\section{Нозологія \\ Nosology}

Карликовість, не класифікована в інших рубриках, Е34.3

тип Ларона (синдром Ларона)

Dwarfism, not heading classified, Laron type (Laron

syndrome)

Цукровий діабет новонароджених

P70.2

Neonatal diabetes mellitus

Інсулінонезалежний цукровий діабет без

E11.9

акромегалією. 3 лікуванням акромегалії в Україні ще складніше, чим зі статистикою, оскільки препарати, що використовуються для корекції гіперсоматотропінемії дороговартісні та потребують пожиттєвого призначення. Багато пацієнтів зі встановленим діагнозом не забезпечені медикаментозними препаратами, що призводить до подальшого ускладнень (діабет зрілого віку в молодих людей

Type 2 diabetes mellitus without complications

(Maturity onset diabetes of the young (MODY)

Ахондрогенезія

Achondrogenesis

Ахондроплазія, гіпохондроплазія

Achondroplasia, hypochondroplasia

Спондилоепіфізарна дисплазія

Spondyloepiphyseal dysplasia

Незавершений остеогенез

Q77.0

Q77.4

Q77.7

Osteogenesis imperfecta

Нейрофіброматоз (незлоякісний)

Neurofibromatosis (non-cancerous)

Синдроми природжених вад, що проявляються

переважно карликовістю

Синдром Рассела - Сільвера, Синдром

Прадера - Віллі

Syndromes of congenital malformations, manifested

mainly by dwarfism

Russell-Silver syndrome, Prader-Willi syndrome

Синдром Тернера (синдром Шерешевського -

Тернера)

Turner syndrome (Shereshevsky — Turner

syndrome)

Гіперпролактинемія (пролактинома)

Q78.0

Q85.0

Q87.1

Hyperprolactinemia (prolactinoma)

Q96.0

96.4,

Q96.8,

Q96.9

D35.2

E22.1

Краніофарингіома

Craniopharyngioma

Злоякісне новоутворення підшлункової залози

Pancreatic adenocarcinoma

Злоякісне новоутворення яєчка

D44

C25

Testis adenocarcinoma

Злоякісне новоутворення щитоподібної залози

Thyroid carcinoma

Злоякісне новоутворення наднирника

Adrenal cancer

прогресування захворювання. I це на тлі того, що у світову клінічну практику впроваджена ціла низка фармакологічних засобів (аналоги соматостатину, антагоністи рецепторів гормону росту та дофамінових рецепторів), які дозволяють значно підвищити ефективність комбінованого лікування аденом гіпофізу. 
За останні десятиліття в багатьох країнах світу було створено або створюються національні реєстри пацієнтів із різними соціально значущими захворюваннями, включаючи акромегалію, що дає можливість планувати та забезпечувати пацієнтів необхідними препаратами. Опубліковані дані бельгійських, британських, фінських, іспанських та інших національних реєстрів пацієнтів з акромегалією [8-11]. Низка інших європейських країн ініціювали створення цих національних реєстрів. На жаль, в Україні до сьогодні реєстр пацієнтів з акромегалією не створено, що призводить до зниження якості життя та розвитку ускладнень.

Наводимо клінічний випадок діагностики та тактики ведення пацієнтки з акромегалією.

Пацієнтка К, 1962 р.н., у червні 2020 р. звернулася на консультацію зі скаргами на періодичний головний біль, виражену слабкість, підвищену втомлюваність, незначну (2 кг за 6 міс.) втрату ваги.

Вважає себе хворою з 2016 р., коли почала відмічати зміну рис обличчя (збільшення хрящів носа та вушних раковин), збільшення розмірів кистей та стоп (за рік змінила кілька розмірів взуття), періодичний головний біль. У травні 2017 р. звернулася з цими скаргами до ендокринолога, який порекомендував лабораторне обстеження та проведення МРТ гіпофізу. За результатами лабораторного обстеження виявлено гіперсоматотропінемію (СТГ $-16,2$ нг/мл (референтні значення (рз): 0,01-3,607 нг/мл), ІФР-1-628 нг/мл (рз: 36-200 нг/мл), пролактин - 9,4 нг/мл (рз: 2,8-29,2 нг/мл).

При прицільній МРТ гіпофізу: розташування турецького сідла звичайне, його порожнина асиметрично розширена, краї дна та стінок чітко відмежовані від оточуючих тканин. Гіпофіз збільшений, розмірами 15,5×19,0×9,6 мм; диференціація долей збережена. Нейрогіпофіз без видимих змін. Структура аденогіпофізу на нативних зображеннях неоднорідна за рахунок наявності в правих відділах патологічного об'ємного утворення загальними умовними розмірами $12,0 \times 12,7 \times 8,6$ мм, що має дещо неоднорідний ізоінтенсивний магнітно-резонансний сигнал на T2WI та помірно гіпоінтенсивний магнітно-резонансний сигнал на T1WI. Під час проведення динамічного дослідження 3 в/в болюсним введенням контрастної речовини вказане утворення має ознаки уповільненого та значно зниженого накопичення контрасту зі збереженням на відтермінованих зображеннях, що характерно для аденоми. Латеральний контур аденоми досягає медіального контуру інтракавернозного сегмента внутрішньої сонної артерії праворуч, але ознак компресії артерії та інвазії процесу в кавернозний синус не виявлено. Медіальний контур аденоми пролабує в супраселлярну цистерну, стебло гіпофізу деформоване, із девіацією ліворуч. Без відхилень від норми визначаються області перехресту зорових нервів та надсідловидної цистерни підоболонкового простору, заповненого спинномозковою рідиною. Кавернозний синус і кавернозний відділ внутрішньої сонної артерії без видимих змін. Прилеглі відділи головного мозку не змінені.

Проведено додаткові діагностичні дослідження:

Аналіз крові: тиреотропний гормон 1,34 мОд/л (р3: 0,4-4,0 мОд/л), тироксин вільний - 1,42 нг/дл (рз: 0,89-1,76 нг/дл), пролактин - 16,5 нг/мл (рз: 2,8-29,2 нг/мл).

Загальний аналіз крові: еритроцити $4,44 \times 10^{12} /$ л $\quad$ (рз: $\left.(3,9-5,2) \times 10^{12} / л\right)$, гемоглобін - 139 г/л (рз: 120-156 г/л), гематокрит 37,1 (рз: 35,5-45,5), тромбоцити $-215 \times 10^{9} /$ л (р3: $(166-389) \times 10^{9} /$ л), лейкоцити $-3,2 \times 10^{9} /$ л (р3: $\left.(3,9-10,2) \times 10^{9} / л\right)$, швидкість осідання ритроцитів - 10 мм/год (рз: <15 мм/год).

Біохімічний аналіз крові: загальний білок - 69,3 г/л (рз: 65-86 г/л), сечовина 3,4 ммоль/л (р3: 2,1-8,2 ммоль/л), креатинін - 112 мкмоль/л (рз: 71-115 мкмоль/л), холестерин загальний - 4,61 ммоль/л (рз: <5 ммоль/л), білірубін загальний 20,0 мкмоль/л (рз: 0-21 мкмоль/л), АлАТ 12,8 Од/л (рз: 0-45 Од/л), АсАТ - 14,9 Од/л (рз: 0-40 Од/л), глюкоза - 4,8 ммоль/л (рз: 4,1-6,0 ммоль/л).

Електрокардіограма: синусова аритмія зі схильністю до сповільнення частоти серцевих скорочень; електрична вісь серця відхилена вліво; порушення провідності по правій ніжці пучка Гіса; помірні зміни міокарда; не виключена гіпертрофія лівого шлуночка.

Рентгенографія органів грудної клітки: інфільтративно-вогнищевої патології не виявлено.

Дослідження функції зовнішнього дихання: нормальна спірометрія. 
Огляди

Ультразвукове дослідження щитоподібної залози: залоза розташована в типовому місці, збільшена за рахунок обох долей. В обох долях визначаються утворення: у правій долі - множинні розмірами від 4 до 11 мм, у лівій долі 4, розмірами від 5 до 12 мм, правильної форми, із чіткими межами. Тканина утворень ізоехогенна. Ехоструктура неоднорідна за рахунок ділянок кістоподібної дегенерації. Інша тканина залози помірно гіпоехогенна. Ехоструктура неоднорідна за рахунок наявності множинних дрібних анехогенних включень. Регіонарні лімфатичні вузли не візуалізуються. Сумарний об'єм за методом Brunn - 18,89 см³; права доля $-9,61 \mathrm{~cm}^{3}$, ліва доля $-9,28 \mathrm{~cm}^{3}$. Висновок: ехографічна картина змішаного зоба II ступеня.

Ультразвукове дослідження органів черевної порожнини: ознаки хронічного холециститу і хронічного панкреатиту.

На підставі результатів лабораторних та інструментальних досліджень встановлено клінічний діагноз: ендосупраселлярна СТГпродукуюча аденома гіпофіза; синдром акромегалії; змішаний зоб II ступеня; еутиреоз.

Зважаючи на наявність об'ємного утворення, $з$ найбільшою вірогідністю аденоми гіпофіза (соматотропіноми), та враховуючи результати обстеження, пацієнтка скерована на консультацію до нейрохірурга. 8.08.17 р. проведено трансназальне транссфеноїдальне ендокапсулярне видалення аденоми гіпофізу. Патогістологічний висновок: морфологічна картина відповідає ацидофільній аденомі гіпофіза. Післяопераційний період - без особливостей. Медикаментозне лікування не призначено.

Через 3 міс. після оперативного втручання пацієнтка пройшла контрольне обстеження. Результати лабораторних досліджень: СТГ 0,4 нг/мл (рз: 0,01-3,607 нг/мл), ІФР-1 204 нг/мл (рз: 36-200 нг/мл), тиреотропний гормон - 0,9 мОд/л (рз: 0,4-4,0 мОд/л), тироксин вільний - 0,8 нг/дл (рз: 0,89-1,76 нг/дл), пролактин - 5,4 нг/мл (рз: 2,8-29,2 нг/мл), кортизол - 8,6 мкг/дл (рз: 4,3-22,4 мкг/дл).

МРТ гіпофізу: турецьке сідло сплощене, розміри в межах норми. Патологічних об’ємних утворень у гіпофізарній зоні не виявлено. Гіпофіз розташований на дні турецького сідла, злегка деформований. Розміри гіпофіза 3,8×12,0×10 мм. Воронка злегка відхилена вліво. Надселлярна група цистерн без особливостей. Хіазма не змінена. Параселлярні структури без особливостей. Висновок: стан після трансназальної транссфеноїдальної аденомектомії ендосупраселлярної аденоми гіпофізу. 3 метою терапії вторинного гіпотиреозу призначено L-тироксин у дозі 50 мкг на добу.

Восени 2019 р. пацієнтка почала відмічати повернення симптомів - головний біль, збільшення розмірів стоп, виражену слабкість і підвищену втомлюваність на фоні прийому L-тироксину в дозі 50 мкг на добу. При лабораторному дослідженні: СТГ - 3,3 нг/мл (рз: 0,01-3,607 нг/мл), ІФР-1-288,4 нг/мл (рз: 36200 нг/мл), тиреотропний гормон - 0,6 мОд/л (рз: 0,4-4,0 мОд/л), тироксин вільний 1,2 нг/дл (рз: 0,89-1,76 нг/дл), пролактин 6,2 нг/мл (рз: 2,8-29,2 нг/мл), кортизол 5,1 мкг/дл (рз: 4,3-22,4 мкг/дл).

При проведенні МРТ головного мозку виявлено ознаки рецидиву аденоми гіпофізу: у селлярній ділянці візуалізується утворення неправильної форми $7 \times 4 \times 6$ мм. У січні 2020 р. пацієнтці проведено повторне трансназальне транссфеноїдальне видалення аденоми гіпофізу. Операція та післяопераційний період - без особливостей. Пацієнтка продовжувала приймати L-тироксин у дозі 50 мкг на добу.

У зв'язку 3 епідеміологічною ситуацією контрольне обстеження пацієнтка пройшла в червні 2020 р. та звернулася за консультацією в ДУ «Інститут ендокринології та обміну речовин ім. В.П. Комісаренка НАМН України».

Об'єктивний статус: Ріст - 167 см, вага 84 кг, індекс маси тіла - 30,1 м²/кг.

Тілобудова нормостенічна. Шкіра помірної вологості. Язик вологий, збільшений в розміpax, із відбитками зубів. Кістково-суглобовий апарат: збільшені лобні горби, вилицеві дуги, прогнатизм, діастема на верхній та нижній щелепах, збільшені ступні та кисті. Дифузний зоб II ступеня, неоднорідна. Дихання везикулярне. Тони серця звучні. Частота серцевих скорочень - 88 уд/хв. Артеріальний тиск 130/80 мм рт. ст. Живіт м'який, безболісний. Очні симптоми негативні; екзофтальм відсутній.

Результати лабораторних досліджень: СТГ - 5,09 нг /мл (рз: 0,01-3,607 нг/мл), ІФР-1 465,7 нг/мл (р3: 36-200 нг/мл), тиреотропний гормон - 0,4 мОд/л (рз: 0,4-4,0 мОд/л), 
тироксин вільний - 0,98 нг/дл (рз: 0,891,76 нг/дл), пролактин - 5,1 нг/мл (рз: 2,829,2 нг/мл), кортизол - 6,0 мкг/дл (рз: 4,322,4 мкг/дл), глікований гемоглобін - 5,4\% (рз: 4,0-5,6\%), глюкоза - 4,93 ммоль/л (рз: 4,1-6,0 ммоль/л). Аналіз добової сечі на кортизол - 64 мкг/добу (рз: 58-403 мкг/добу).

Консультація невропатолога: дисциркуляторна енцефалопатія II стадія, астено-невротичний, цефалгічний, вестибуло-атаксичний синдроми. Розповсюджений остеохондроз хребта.

Консультація окуліста: ангіопатія сітківки обох очей.

Консультація гінеколога: менопауза.

Консультація кардіолога: ішемічна хвороба серця: стабільна стенокардія напруги 2 функціональний клас; атеросклеротичний кардіосклероз, атеросклероз аорти; гіпертонічна хвороба 2 стадія, 2 ступінь, ризик 3 (високий); серцева недостатність I стадія.

Діагноз: Рецидив аденоми гіпофіза (соматотропіноми). Акромегалія, пухлинна стадія, активна форма. Стан після повторних операцій 3 приводу аденоми гіпофіза (2017 р., 2020 р.). Післяопераційний гіпопітуїтаризм: вторинний гіпотиреоз у стані медикаментозної компенсації. Змішаний зоб II ступеня. Ішемічна хвороба серця: стабільна стенокардія напруги 2 функціональний клас. Атеросклеротичний кардіосклероз, атеросклероз аорти. Гіпертонічна хвороба 2 стадія, 2 ступінь, ризик 3 (високий). Серцева недостатність I стадія. Дисциркуляторна енцефалопатія II стадія, астено-невротичний, цефалгічний, вестибулоатаксичний синдроми. Розповсюджений остеохондроз хребта. Хронічний холецистит у стадії ремісії. Хронічний панкреатит у стадії ремісії.

Враховуючи прогресування хвороби і збереження гіперсоматотропінемії, пацієнтці рекомендовано лікування аналогами соматостатину. Проведено 3-денний тест 3 аналогом соматостатину короткої дії (октреотид 1,0 мл підшкірно 3 рази на добу) з подальшим контрольним визначенням рівнів СТГ та IФP-1. Враховуючи позитивний результат 3-денного тесту з октреотидом (зниження рівня ІФР-1 з 465,7 до 267,0 нг/мл (рз: 36-200 нг/мл) на тлі визначення з 10-денним інтервалом), пацієнтці рекомендована тривала супресивна терапія пролонгованим аналогом соматостатину (ланреотид) - 120 мг підшкірно 1 раз на
28 днів під контролем СТГ та ІФР-1. Також рекомендовано продовжити прийом тироксину в дозі 50 мкг на добу.

Не менш складною є ситуація за орфанних спадкових синдромів поєднаного пухлинного ураження різних ендокринних залоз - множинних ендокринних неоплазіях (MEH, поліендокринопатіі). Виділяють наступні форми таких синдромів: МЕН1, МЕН2А (4 варіанти), МЕН2B, МЕН4, хвороба фон Гіппеля-Ліндау (ХФГЛ), нейрофіброматоз 1 типу, комплекс Карнея та синдром МакК'юна-Олбрайта.

МЕН 1 типу (МЕН1) - ендокринний пухлинний синдром, викликаний інактивуючими мутаціями пухлинного гена-супресора $M E N 1$ у 11q13 локусі. Успадковується автосомно-домінантно, але також може виникати спорадично (без сімейного анамнезу) як результат нових мутацій. МЕН1 характеризується комбінацією паратиреоїдних пухлин, пухлин острівцевих клітин підшлункової залози і пухлин аденогіпофізу. Більшість МЕН1 пухлин - неагресивні i багато 3 них мають тривалий повільно прогресуючий розвиток, залишаючись безсимптомними роками. Але пацієнти з нелікованим MEH1 мають зменшену тривалість життя з 50\% вірогідністю смерті до 50 років [12].

Первинний гіперпаратиреоз внаслідок гіперплазії i/або аденоми прищитоподібних залоз - найбільш частий прояв МЕН1 і виникає в близько 90\% пацієнтів [13]. Первинний гіперпаратиреоз за МЕН1 має тривалий безсимптомний перебіг і зазвичай діагностується як випадкова знахідка підвищеного рівня паратгормону в плазмі пацієнтів із гіперкальціємією, i, у деяких випадках, із нормокальціємією. Клінічні прояви можуть включати гіперкальціємію, нефролітіаз і порушення будови кісткової тканини (генералізована фіброзна остеодистрофія). Первинний гіперпаратиреоз у складі МЕН1 відрізняється від не-МЕН1 первинного гіперпаратиреозу наступним [14]:

- молодший вік початку захворювання (2025 років),

- залученість кількох прищитоподібних залоз,

- високий рівень рецидиву гіперкальціємії після паратиреоїдектомії (50\% через 8-12 років після оперативного втручання).

Другим за частотою (30-80\% пацієнтів) серед МЕН1 є пухлини острівцевих клітин 


\section{Огляди}

підшлункової залози, які можуть бути представлені наступними варіантами [12]:

- гастриноми,

- інсуліноми,

- глюкагономи,

- вазоактивні інтестинальні поліпептидоми,

- панкреатичні поліпептидоми (ППоми).

Для цих пухлин характерна мультицентричність і здатність проходити злоякісне переродження. Найчастіше пухлини підшлункової залози в складі МЕН1 є гормонально-неактивними. Вони або не виділяють гормони, або виділяють гормонально-неактивні пептиди, такі як панкреатична поліпептидаза, хромогранін А, нейротензин, нейроспецифічна енолаза або грелін. Гормонально-неактивні пухлини підшлункової залози, особливо малого розміру ( $<2$ см), важко діагностувати стандартними візуалізаційними методами. В таких випадках є ефективним чутливий радіологічний скринінг. Вчасна діагностика цих пухлин дуже важлива, тому що до віку 80 років пенетрантність панкреатичних пухлин складає більше $80 \%$, а найбільш частою причиною смертності, пов'язаної з МЕН1, є метастатичне ураження $[15,16]$.

Гастриноми - найбільш часті серед гормонально-активних панкреатичних нейроендокринних пухлин і виникають у 40-55\% пацієнтів [16]. Розвитку гастрином передує багатофокусна гіперплазія гастрин-продукуючих клітин. Порівняно з не-МЕН1 гастриномами при синдромі Золінгера-Еллісона або при МЕН1 часто невеликого розміру ( $<0,5$ см), мультицентричні і локалізовані у дванадцятипалій кишці, зменшуючи вірогідність успішного хірургічного лікування. Близько 20-30\% пацієнтів із синдромом Золінгера-Еллісона мають МЕН1. Серед пацієнтів із МЕН1, синдром Золінгера-Еллісона зустрічається тільки в пацієнтів із первинним гіперпаратиреозом [12]. Тривалий перебіг МЕН1 і синдрому Золінгера-Еллісона може призвести до розвитку карциноїдних пухлин шлунка, зокрема, високоагресивних [18].

Інсуліноми займають друге місце по частоті серед гормонально-активних панкреатичних нейроендокринних пухлин за МЕН1. Вони діагностуються в молодому віці ( $<35$ років) у близько 10-30\% пацієнтів. Інсуліноми при MEH1 можуть маніфестувати як одиничні макроаденоми підшлункової залози (>2 см) або, частіше, як множинні мікроаденоми ( $<2$ см), розкидані по всій підшлунковій залозі [19]. Інсуліноми можуть бути мультицентричними і метастазувати в регіонарні лімфовузли або печінку [12].

Глюкагономи в пацієнтів із МЕН1 виникають рідко ( $<3 \%$ випадків) і можуть протікати без змін вуглеводного обміну або з гіперглікемією. У деяких пацієнтів спостерігається типове ураження шкіри, відоме як некролітична мігруюча еритема. Іншими симптомами можуть бути: анемія, стоматит, втрата ваги, але часто вони відсутні.

У менше 1\% пацієнтів із МЕН1 у підшлунковій залозі виникають вазоактивні інтестинальні поліпептидоми - пухлини, які секретують панкреатичний поліпептид або гормон росту [12].

МЕН1-асоційовані пухлини аденогіпофізу найбільш часто секретують пролактин (60\%) і гормон росту (25\%). Менше ніж 5\% пухлин секретують кортикотропін, інші пухлини - гормонально-неактивні [12]. Порівняно $з$ не-МЕН1 пухлинами аденогіпофізу, MEH1 пухлини аденогіпофізу є більшими за розміром (макроаденоми) і більш агресивними, з більшим рівнем інфільтрації пухлинних клітин у нормальну тканину аденогіпофізу. MEH1-асоційовані пухлини аденогіпофізу важче піддаються лікуванню. Водночас вираженої гістологічної різниці між МЕН1 і неМЕН1 пухлинами аденогіпофізу немає [20].

Також у пацієнтів із МЕН1 можуть виникати карциноїдні пухлини в бронхах, шлунково-кишковому тракті, підшлунковій залозі та тимусі. Карциноїд тимусу, асоційований із MEH1, часто гормонально-неактивний і високоагресивний [21]. Карциноїди можуть активно секретувати серотонін, соматостатин, кортикотропін і гормон росту.

Для МЕН1 характерні шкірні прояви: підшкірні ліпоми виявляються в третини пацієнтів із МЕН1. Ці новоутворення мають втрату гетерозиготності в сегменті 11q12-12 і асоційовані з дефективним функціонуванням глобулярного протеїна. Ліпоми за МЕН1 можуть бути ретроперитонеальними, вісцеральними або плевральними. Наявність ангіофібром i колагеном на обличчі може дозволити досимптомне встановлення діагнозу МЕН1 у родичів пацієнта з встановленим діагнозом [12]. 
Пухлини надниркових залоз виникають у 20-40\% пацієнтів із МЕН1. Ці пухлини, як правило, доброякісні і представлені гормонально-неактивними кортикальними аденомами або дифузною або нодулярною гіперплазією [22, 23]. Адренокортикальні карциноми при МЕН1 зустрічаються рідко.

Аденома щитоподібної залози зустрічається в 5-30\% пацієнтів і не має специфічних ознак, пов'язаних із МЕH1.

Зустрічаються менінгіоми та інші пухлини центральної нервової системи.

Нейроендокринна пухлина тимуса становить рідкісний (3,7\% пацієнтів із МЕН1), але фатальний компонент МЕН1, на рахунку якого майже 20\% МЕН1-асоційованої смертності [24].

Ген, який відповідає за розвиток МЕН1 локалізований у сегменті 11q13 і кодує білок менін. Менін задіяний у регуляції транскрипції i геномної стабільності. Втрата гетерозиготності цієї ділянки асоційована з МЕН1 - це дає підстави вважати, що ген має пухлинносупресорну функцію. Пацієнти успадковують одну мутовану копію гена і їм залишається отримати соматичну мутацію другої копії для розвитку пухлини. МЕН1 - автосомно-домінантне захворювання, але також виникають спорадичні мутації. Ідентифікація і генетична характеристика причинного гена відкрила можливість генетичного тестування і ранньої діагностики захворювання. Аналіз послідовності в гені MEN1 для виявлення мутацій забезпечує найточніше підтвердження статусу носія гена. 3 розвитком нових технологій, таких як мультиплексна ампліфікація лігованих зондів, були відкриті нові мутації в гені $M E N 1$, що підвищує чутливість генетичного аналізу. У минулому генетичне тестування не знаходило мутації MEN1 у 10-30\% пацієнтів, в яких були клінічні критерії для діагнозу MEH1 (наявність щонайменше двох MEH1асоційованих пухлин: первинний гіперпаратиреоз, дуоденопанкреатичні нейроендокринні пухлини і пухлини аденогіпофізу) [25]. Таких пацієнтів називають фенокопіями. Наявність фенокопії передбачається при негативному тесті $M E N 1$ за послідовністю, генною дозою і аналізом гаплотипу 11q13. Фенокопії нараховують до 5\% МЕН1-подібних випадків, у більшості випадків пов'язані з захворюваннями прищитоподібних залоз і аденогіпофіза [26].
Відповідно до даних рандомізованих досліджень частота МЕН1 становить від 1 випадку на 10000 чол. до 1 випадку на 100000 чол. [12, 27]. Характерне формування географічних кластерів як наслідок ефекту засновників (у популяційній генетиці - явище втрати генетичної мінливості при формуванні нової популяції невеликою кількістю людей із більшого числа населення) [28]. Ген MEN1 має високу пенетрантність. До віку 20 років ген пенетрантний у $50 \%$ і до віку 40 років пенетрантний у 95\%. Не було ідентифіковано випадків типових ознак, асоційованих зі статусом носія гена $M E N 1$ у пацієнтів, молодше 5 років; таким чином, ген не пенетрантний до цього віку [12, 13].

Тактика лікування при МЕН1 залежить від наявних ендокринопатій та стратифікації ризиків. Основним методом лікування пацієнтів із МЕН1 є хірургічне видалення пухлин, у низці випадків показані превентивні втручання [27].

Неліковані пацієнти з МЕН1 мають знижену тривалість життя $350 \%$ вірогідністю смерті до 50 років. Причини смерті пов'язані зі злоякісними пухлинами або наслідками ендокринних порушень [12]. Злоякісні нейроендокринні пухлини підшлункової залози або карциноїдні пухлини тимусу пов'язані зі зростанням ризику смерті в пацієнтів із МЕН1. Близько 70\% пацієнтів із МЕН1 помирають від причин, які прямо пов'язані з МЕН1 [17].

Синдром множинної ендокринної неоплазії 2 типу (МЕН2) - спадкове захворювання, яке характеризується розвитком медулярної карциноми щитоподібної залози, пухлин прищитоподібних залоз і феохромоцитоми. МЕН2 виникає внаслідок мутацій у RET-протоонкогені і передається автосомнодомінантно.

Є два МЕН2 синдроми: МЕН2A і МЕН2B (раніше мав назву МЕН3).

МЕН2А далі класифікується на 4 варіанти, відповідно до наявності його складових. Класичний МЕН2А характеризується медулярною карциномою щитоподібної залози, первинним гіперпаратиреозом і феохромоцитомою. Три додаткові варіанти складають: МЕН2А з вузликовим амілоїдозом шкіри, МЕН2А з хворобою Гіршпрунга і сімейна медулярна карцинома, яка діагностується, коли в пацієнта є патологічний 
$R E T$ геном і медулярна карцинома, але в сімейному анамнезі відсутні феохромоцитома або гіперпаратиреоз [30].

MEH2B менш частий, ніж MEH2A, і нараховує 5\% випадків МЕН2. Він характеризується більш агресивною медулярною карциномою (яка виникає в 100\% випадків), феохромоцитомою (50\%), мукозними невромами (95\%-98\%) i гангліоневромами (40\%). Гіперпаратиреоз відсутній. До того ж, майже в усіх пацієнтів виявляється марфаноїдна тілобудова: високе піднебіння, лійковидна деформація грудної клітки, високе склепіння стоп, сколіоз, виступаючі губи. Часто виникають невроми на повіках, кон'юнктиві, слизовій носа і гортані, язику і губах [31].

Медулярна карцинома розвивається фактично в усіх пацієнтів із МЕН2. Найчастіше це перший прояв синдрому, який виникає впродовж першої-третьої декади життя. У пацієнтів із МЕН2А медулярна карцинома, як правило, двостороння (на відміну від спорадичної медулярної карциноми, яка є односторонньою) і багатофокусна, ïi розвитку передує гіперплазія С-клітин [32].

Обгрунтування генотип-фенотипової кореляції спадкової медулярної карциноми може скерувати розвиток індивідуального підходу до оцінки і контролю ризиків у дітей-носіїв генотипу. Для довгострокового попередження розвитку медулярної карциноми в пацієнтів iз МЕH2 є ефективною рання тотальна тиреоїдектомія [33, 34, 35].

Феохромоцитоми присутні в близько половини МЕН2А пацієнтів. Вони двосторонні в $60-80 \%$ випадків, у той час як спорадичні феохромоцитоми двосторонні в 10\%. Феохромоцитоми діагностуються одночасно з медулярною карциномою або через декілька років. Феохромоцитоми в складі МЕН2А майже завжди доброякісні, але вони можуть спричиняти загрозливі для життя гіпертонічні кризи або напади аритмії.

Гіперпаратиреоз присутній у близько половини пацієнтів із МЕН2А, але виявляється рідше ніж феохромоцитоми. Найчастіше проявляється в пацієнтів після 30 років. Гістологічно прищитоподібні залози при МЕН2А складаються з гіперплазованих головних клітин і ця гіперплазія є асиметричною відносно розмірів прищитоподібної залози.
Спостерігається підвищена частота додаткових прищитоподібних залоз [36]. Персистуючий або рецидивуючий гіперпаратиреоз не характерний для МЕH2А на відміну від пацієнтів із МЕН1.

MEH2 спричиняють мутації в трансмембранному протоонкогені $R E T$, які локалізуються в 10q11.21. Функція білка, закодованого $R E T$, залишається невизначеною, але відомо, що він є важливим під час ембріонального розвитку нервової системи кишечника і нирок. RET складається з 3 доменів, включаючи домен цистеїнвмісного позаклітинного рецептора, гідрофобний трансмембранний домен i внутрішньоклітинний тирозинкіназний каталітичний домен [37, 38].

Позаклітинний домен взаємодіє з одним із чотирьох лігандів, відомих сьогодні. Ці ліганди - гліальна клітинна лінія - похідне нейротропного фактора (гліальний нейротрофічний фактор), нейротурин, персефін і артемін також взаємодіють $з$ одним із чотирьох корецепторів сімейства рецепторів гліального нейротрофічного фактора - альфа-сімейством. Гліальний нейротрофічний фактор відіграє важливу роль у нормальному функціонуванні шляхів, задіяних у нейрогенезі нервової системи кишечника і нирковому органогенезі. Тирозинкіназний каталітичний центр знаходиться у внутрішньоклітинному домені і викликає низхідні сигнальні впливи через різні молекули - вторинні месенджери [39].

Точкові мутації, асоційовані з МЕН2A і iï підтипом сімейною медулярною карциномою ідентифіковані в екзонах 10 і 11. Доведена генотипно-фенотипна кореляція. Класична МЕН2А асоційована 3 міссенс-мутацією зародкової лінії в кодонах 609, 611, 618 або 620 екзону 10 або кодону 634 екзону 11 у RETпротоонкогені. МЕН2А з вузликовим амілоїдоом шкіри майже завжди асоційована з мутацією кодону 634, у той час, коли пацієнти з МЕН2А і хворобою Гіршпрунга типово мають мутації в екзоні $10 R E T$ [40].

Є дані, що пацієнти з мутацією в кодоні A883F мають більш латентний розвиток захворювання порівняно з носіями М918Т із більш пізньою маніфестацією феохромоцитом [41].

Близько 75\% випадків МЕН2В спорадичні і пацієнти мають RET-мутації de novo, у той час як $25 \%$ випадків виникають у родинах із 
проявами МЕН2В у минулому або в даний час. Майже 95\% пацієнтів із МЕН2B мають мутацію зародкової лінії RET у екзоні 16 (кодон M918T) і менше ніж 5\% мають мутацію зародкової лінії RET у екзоні 15 (кодон А883F) [30].

Загальна частота МЕН2 складає 1 випадок на 30 000-50 000 чол. [42, 43].

Найбільш частими видами МЕН2 є: MEH2A, МЕН2А з сімейною медулярною карциномою і МЕН2B.

Серед пацієнтів МЕН2А з мутацією гена $R E T$ захворювання виявляється: до 50 років у $50 \%$, і до 70 років - у 70\%. Медулярна карцинома в пацієнтів із МЕН2В зустрічається в ранньому дитячому віці.

Лікування МЕН2 - хірургічне. До проведення паратиреоїдектомії або тиреоїдектомії обов'язково потрібно виключити феохромоцитому. Якщо феохромоцитома діагностована, втручання $з$ iii приводу проводиться першочергово 3 огляду на можливу гемодинамічну нестабільність [44, 45]. При метастатичних ураженнях можуть бути застосовані інгібітори тирозинкінази.

При МЕН2 раннє лікування медулярної карциноми щитоподібної залози може запобігти смерті, а ретельний моніторинг феохромоцитоми може зменшити ризик гіпертензивних кризів. Враховуючи, що пенетрантність медулярної карциноми при МЕН2 складає близько $100 \%$, у пацієнтів із високим ризиком мутацій $R E T$ профілактична тиреоїдектомія показана в немовлячому віці, а в дітей із виявленими мутаціями $R E T$ - до 5-річного віку [46, 47].

MEH4 має клінічні прояви подібні до МЕН1, але викликана мутаціями в іншому гені. Найбільш типовим проявом МЕH4 є гіперпаратиреоз, на другому місці - пухлини аденогіпофізу. Ризик розвитку панкреатичних нейроендокринних пухлин у пацієнтів із MEH4 значно нижчий ніж у пацієнтів із MEH1 [48].

При MEH4 виникають мутації в гені циклін-залежного інгібітора кінази $(C D K N 1 B)$. Цей ген відповідає за синтез білка р27. Як і менін (який кодується геном MEN1), p27 - пухлинний супресор, що допомагає контролювати ріст і ділення клітин. Мутації в гені $C D K N 1 B$ зменшують кількість функціонуючого р27, що призводить до безконтрольного росту і розмноження клітин. Таке некероване ділення клітин може призвести до розвитку пухлин в ендокринних залозах та інших тканинах.

Задокументовано 12 підтверджених випадків MEH4; за розрахунковими даними їі частота в загальній популяції може становити менше 1 випадку на 1 млн чол.

Хвороба фон Гіппеля-Ліндау (ФГЛ) - рідкісне генетичне захворювання, яке характеризується вісцеральними кістами і доброякісними пухлинами в багатьох органах, які мають потенціал до злоякісного переродження. Клінічні прояви хвороби ФГЛ включають розвиток гемангіом сітківки та центральної нервової системи, феохромоцитом, множинних кіст у підшлунковій залозі та нирках і підвищений ризик трансформації ниркових кіст у рак нирки $[49,50]$. Широкий діапазон віку і різноманітність форм, у яких проявляється хвороба ФГЛ, ускладнює діагностику і лікування уражених пацієнтів, а також їх родичів. Гемангіоми сітківки діагностуються в 50\% пацієнтів із хворобою ФГЛ. Пухлини центральної нервової системи та інших органів виникають у $25 \%$ пацієнтів із хворобою ФГЛ. Пацієнти з хворобою ФГЛ мають підвищений ризик розвитку феохромоцитом, які можуть бути двосторонніми. Феохромоцитоми виникають у 10-50\% пацієнтів із хворобою ФГЛ, залежно від субтипу, обумовленого видом мутації в причинному гені. Більшість (70\% випадків) панкреатичних уражень є простими кістами і зрідка бувають із клінічними проявами або перероджуються в злоякісні пухлини.

Хвороба ФГЛ успадковується автосомнодомінантно. Нові мутації виникають у близько 1:4,4 мільйони новонароджених і складає 20\% випадків. Загальна частота хвороби ФГЛ у світі складає 1:32000 новонароджених, у США - 1:36000 новонароджених. Вік встановлення діагнозу коливається від раннього дитячого до 60-70 років і в середньому складає 26 років [51].

Ген фон Гіппеля-Ліндау розміщений на короткому плечі 3 хромосоми (3p25.3) і кодуе широко експресовану іРНК, яка у свою чергу кодує 3 екзони 3 альтернативним сплайсингом [52]. У результаті два синтезовані білки фон Гіппеля-Ліндау, 30кДа форма (30p) i 19 кДа форма (р19), складають човниковий механізм між ядром та цитоплазмою, де вони утворюють комплекси 3 іншими білками. Ці 
білкові комплекси мають багато функцій: регуляція старіння, кисне-чутливий шлях, мікротубулярна стабільність і орієнтація, формування війок, цитокінова сигнальна система, збирання колагену IV типу в позаклітинному матриксі, регуляція збирання нормального позаклітинного фібронектинового матриксу і пухлинна супресія [51].

Середня тривалість життя в пацієнтів із хворобою ФГЛ складає 49 років, в основному через високу частоту асоційованого світлоклітинного раку нирки. Але ретельні обстеження, які дозволяють провести ранні втручання можуть подовжити тривалість життя таких пацієнтів.

Нейрофіброматоз 1 типу (НФ1) - мультисистемне генетичне захворювання, яке характеризується шкірними проявами у вигляді плям кольору «кави 3 молоком» і пахвовим лентіго, кістковими дисплазіями і розвитком доброякісних і злоякісних пухлин нервової системи, найчастіше нейрофібром. Ендокринологічний інтерес у НФ1 представляють феохромоцитоми, які зустрічаються приблизно в 5\% пацієнтів [53, 54].

НФ1 виникає внаслідок мутації або делеції в гені NF1. Нейрофібромін, який кодується геном NF1, є пухлинним супресором; зменшена продукція цього білка результує численими клінічними проявами [55].

Розрахункова частота НФ1 складає 1 випадок на 3 000, але насправді може бути більшою через неповне виявлення легких форм захворювання. Близько половини пацієнтів представляють перший випадок у сім’і, як результат нової генетичної мутації [55]. Середня тривалість життя пацієнтів із НФ1 скорочується на 8 років порівняно з загальною популяцією [56].

Комплекс Карнея - автосомно-домінантний синдром, який проявляється плямистою пігментацією шкіри, ендокринопатіями, ендокринними та неендокринними пухлинами [57]. Ці пухлини включають міксоми шкіри, серця, молочних залоз та інших локалізацій: первинну пігментовану нодулярну адренокортикальну хворобу (ППНАХ), псаммоматозні меланотичні шваноми; аденоми аденогіпофізу, що продукують гормон росту, тестикулярні пухлини клітин Сертолі, пухлини щитоподібної залози, аденоми проток молочних залоз, акромегалію внаслідок соматомамотрофної гіперплазії і аденом, незалежних від соматоліберину.
Комплекс Карнея успадковується автосомно-домінантно з варіативною пенетрантністю. Вважається, що кардіальні міксоми виникають із субендотендокардіальних мезенхімальних мультипотентних клітин-попередників. Комплекс Карнея виникає внаслідок мутацій у гені $P R K A R 1 A$, який кодує регуляторну субодиницю протеїнкінази A R1 $\alpha$ [58]. PRKAR1A може грати роль гена-пухлинного супресора, регулюючи активність протеїнкінази А, що у свою чергу може стимулювати або пригнічувати ріст і диференціювання клітин. Гени комплексу Карнея асоційовані з геномною нестабільністю; клітинні лінії, отримані з пухлин комплексу Карнея, накопичують хромосомні перебудови, включаючи асоціації теломер і дицентричні хромосоми [59].

Пухлини ППНАХ характеризуються ліпофусцин-вмісними, кортизол-продукуючими вузлами, які оточені атрофованою адренокортикальною і нормальною адреномедулярною тканиною [60]. Природа виникнення цих пухлин не зрозуміла. Макроскопічно поверхня пухлин вкрита множинними маленькими вузликами чорного або коричневого кольору. Позапухлинна тканина кори надниркових залоз атрофічна. Мікроскопічно множинні вузлики визначаються у всій товщі кори. Клітини в цих вузликах позитивно фарбуються реактивом Шиффа. Поза корою відмічається інтенсивна дезорганізація без нормального зонування.

У близько 75\% пацієнтів із комплексом Карнея зустрічається багатовузловий зоб.

3 моменту виділення комплексу Карнея в окрему клінічну категорію в 1985 році цей діагноз було встановлено близько 600 пацієнтам у світі [61]. Середня тривалість життя пацієнтів із комплексом Карнея становить 5055 років. 25\% смертності пацієнтів із цим синдромом обумовлені кардіальними міксомами. Тривалість життя таких пацієнтів може бути подовжена за умови регулярних обстежень і своєчасних втручань [62].

Синдром МакК’юна-Олбрайта діагностується за наявності щонайменше двох із наступних трьох критеріїв: (1) поліоссальна фіброзна остеодисплазія, (2) пігментація шкіри у вигляді плям кольору «кави з молоком» і (3) автономна ендокринна гіперфункція (наприклад, гонадотропін-незалежне передчасне статеве дозрівання). Також можуть 
бути присутніми інші ендокринні синдроми, включаючи гіпертиреоз, акромегалію, синдром Кушинга, гіперпролактинемію, гіперпаратиреоз, гінекомастію і гіпофосфатемічну остеомаляцію [63].

Синдром МакК'юна-Олбрайта розвивається внаслідок постзиготичної активуючої мутації гена GNAS1 у локусі 20q13.1-13.2, який кодує протеїн G субодиниці Gs альфа в уражених тканинах. Клінічні прояви синдрому дуже варіативні, залежно від того, які з можливих компонентів домінують [64].

Синдром МакК'юна-Олбрайта - дуже рідкісне спорадичне захворювання. Його частота в популяції оцінюється між 1 випадок на 100000 чол. і 1 випадок на 1 млн чол. [65].

Важкі випадки синдрому з залученням множинних ендокринних тканин розпізнаються в період новонародженості. Випадки синдрому Кушинга і гіпертиреозу також були зафіксовані в період новонародженості. Менш важкі форми проявляються в ранньому дитинстві від 0,3 до 9 років. Аденоми гіпофізу, що продукують гормон росту, і токсичні аденоми щитоподібної залози внаслідок GNAS1 мутацій можуть виникати в будь-якому віці. Захворювання з більш пізнім дебютом асоціюються з клінічно більш латентними фенотипами [66].

На сьогодні не існує лікування, спрямованого на причинну молекулярну проблему синдрому. Застосовують різні препарати для корекції ендокринних та метаболічних порушень, включаючи інгібітори ароматази, стероїди, аналоги соматостатину, агоністи дофаміну, бісфосфонати, антагоністи рецепторів естрогену і антитиреоїдні препарати.

При переломах кісток внаслідок диспластичного ураження показане хірургічне втручання. При наявності вузлового або багатовузлового зобу з тиреотоксикозом показане проведення гемітиреоїдектомії або тиреоїдектомії. Лікування синдрому Кушинга в складі синдрому МакК’юна-Олбрайта передбачає двосторонню адреналектомію 3 подальшою стероїдною замісною терапією [67].

Окремо від невеликої підгрупи пацієнтів iз підвищеною периопераційною летальністю i зі злоякісними новоутвореннями, синдром МакК'юна-Олбрайта не пов'язаний із підвищеною смертністю. Захворюваність і втрата працездатності в таких пацієнтів може бути високою внаслідок хронічного болю і деформацій кісткової тканини, а також мультигормональних ендокринопатій. Таким чином, прогноз значною мірою залежить від проявів синдрому МакК'юна-Олбрайта [63].

Враховуючи, що МЕН є мультисистемними захворюваннями з низкою різноманітних проявів, тактика ведення таких пацієнтів є нестандартною і потребує мультидисциплінарного підходу.

Генетичне тестування - базовий елемент у діагностиці МЕН-синдромів. Генетичний скринінг мутацій проводиться в пацієнтів із відповідними клінічними критеріями. Якщо мутація ідентифікована, тим членам сім’і, які знаходяться в зоні ризику, також проводиться скринінг. Ретельні динамічні обстеження пацієнтів із МЕН, а також безсимптомних носіїв дозволяють виявляти новоутворення на ранній досимптомній стадії і своєчасно провести оперативне лікування, що може зменшити ризик пов'язаної смертності.

Останнім часом прослідковується тенденція до збільшення частоти виявлення орфанних захворювань. Причиною даної ситуації може бути покращення методів лабораторної та інструментальної діагностики, використання генетичних методів діагностики та більш широка обізнаність лікарів щодо орфанних захворювань.

З 1996 р. по 2020 р. у хірургічному відділі ДУ «Інститут ендокринології та обміну речовин ім. В.П. Комісаренка НАМН України» пройшли лікування 29 пацієнтів із МЕН: у 10 пацієнтів була діагностована МЕН1, у 13 пацієнтів - MEH2A, у 5 пацієнтів МЕН2B і в 1 пацієнта - синдром фон ГіппеляЛіндау.

У травні 2020 р. МОЗ України ініціювало ухвалення Національної стратегії з профілактики, діагностики та лікування рідкісних (орфанних) захворювань, що свідчить про визнання проблеми на державному рівні.

Таким чином, визначено не тільки перелік орфанних захворювань, але й прийнято рішення щодо важливості лікування рідкісних (орфанних) захворювань та забезпечення пацієнтів життєво необхідними лікарськими засобами та спеціальним харчуванням. Для реалізації Національної стратегії важливим є збір статистичної інформації про орфанні 
Огляди

захворювання в Україні, впровадження ефективних методів ранньої діагностики, лікування та реабілітації пацієнтів, а також підготовка кваліфікованих фахівців. Шлях вирішення даного питання - це забезпечення доступу пацієнтів до високоспеціалізованої медичної допомоги, розробка вітчизняних стандартів 3 імплементацією міжнародних протоколів діагностики та лікування орфанних захворювань, проведення наукових досліджень у сфері рідкісних орфанних захворювань, а також поглиблення національної і міжнародної співпраці в питаннях тактики ведення пацієнтів з орфанними захворюваннями.

\section{Список використаної літератури}

1. European Commission. Non-communicable diseases [Internet] Available from: https://ec.europa.eu/health/non_communicable_ diseases/rare_diseases en.

2. Prevalence of rare diseases: Bibliographic data. Orphanet Report Series, Rare Diseases collection, January 2020, Number 2: Diseases listed by decreasing prevalence, incidence or number of published cases [Internet]. Available from: https://www.orpha.net/orphacom/ cahiers/docs/GB/Prevalence of rare diseases by decreasing prevalence_or_cases.pdf.

3. Закон України «Про внесення змін до Основ законодавства України про охорону здоров'я щодо забезпечення профілактики та лікування рідкісних (орфанних) захворювань» № 1213-VII 15.04.2014 р. Відомості Верховної Ради (ВВР), 2014, № 26, ст. 894. (Law of Ukraine «On modification of Fundamentals of the legislation of Ukraine on health care concerning prevention and treatment of rare (orphan) diseases» N1213-VII 15.04.2014. Vidomosti Verkhovnoyi Rady (VVR), 2014, N26, Art. 894). Available from: https://zakon. rada.gov.ua/laws/show/1213-18/print

4. Міністерство охорони здоров'я України. Що таке орфанні хвороби і як змінюється доступ до лікування (Ministry of Health of Ukraine. What is orphan diseases and how the access to treatment is changing) [Internet]. Available from: https://moz.gov.ua/article/ news/scho-take-orfanni-hvorobi-i-jak-zminjuetsja-dostup-dolikuvannja.

5. Міністерство охорони здоров'я України. Наказ від 27.10.2014 р. № 778 «Про затвердження переліку рідкісних (орфанних) захворювань». (Ministry of Health of Ukraine. Order from 27.10.2014 p. N778 «On the approval of the list of rare (orphan) diseases»). [Internet]. Available from: https://zakon.rada.gov.ua/ laws/show/z1439-14\#Text.

6. Пролактинома. Prolactinoma [Internet]. Available from: https:// www.orpha.net/data/patho/RU/Prolactinoma-RUrusAbs2965 .pdf.

7. Katznelson L, Atkinson JL, Cook DM, Ezzat SZ, Hamrahian AH, Miller KK, et al. American Association of Clinical Endocrinologists medical guidelines for clinical practice for the diagnosis and treatment of acromegaly - 2011 update. Endocr Pract. 2011 Jul-Aug;17 Suppl 4:1-44.

8. Bex M, Abs R, T'Sjoen G, Mockel J, Velkeniers B, Muermans K, et al. AcroBel - the Belgian registry on acromegaly: a survey of the 'real-life' outcome in 418 acromegalic subjects. Eur J Endocrinol. 2007 Oct;157(4):399-409.

9. Jenkins PJ, Bates P, Carson MN, Stewart PM, Wass JA. Conventional pituitary irradiation is effective in lowering serum growth hormone and insulin-like growth factor-I in patients with acromegaly. J Clin Endocrinol Metab. 2006 Apr;91(4):1239-45.

10. Kauppinen-Mäkelin R, Sane T, Reunanen A, Välimäki MJ, Niskanen L, Markkanen $\mathrm{H}$, et al. A nationwide survey of mortality in acromegaly. J Clin Endocrinol Metab. 2005 Jul;90(7):4081-6.

11. Mestron A, Webb SM, Astorga R, Benito P, Catala M, Gaztambide S, et al. Epidemiology, clinical characteristics, outcome, morbidity and mortality in acromegaly based on the Spanish Acromegaly Registry (Registro Espanol de Acromegalia, REA). Eur J Endocrinol. 2004 Oct;151(4):439-46.

12. Thakker RV, Newey PJ, Walls GV, Bilezikian J, Dralle H, Ebeling PR, et al. Clinical practice guidelines for multiple endocrine neoplasia type 1 (MEN1). J Clin Endocrinol Metab. 2012 Sep;97(9):2990-3011.

13. Brandi ML, Gagel RF, Angeli A, Bilezikian JP, Beck-Peccoz P, Bordi $\mathrm{C}$, et al. Guidelines for diagnosis and therapy of MEN type 1 and type 2. J Clin Endocrinol Metab. 2001 Dec;86(12):5658-71.

14. Eller-Vainicher C, Chiodini I, Battista C, Viti R, Mascia ML, Massironi $\mathrm{S}$, et al. Sporadic and MEN1-related primary hyperparathyroidism differences in clinical expression and severity. J Bone Miner Res. 2009 Aug;24(8):1404-10.

15. Triponez F, Dosseh D, Goudet P, Cougard P, Bauters C, Murat A, et al. Epidemiology data on 108 MEN1 patients from the GTE with isolated nonfunctioning tumors of the pancreas. Ann Surg. 2006 Feb;243(2):265-72.

16. Thomas-Marques L, Murat A, Delemer B, Penfornis A, CardotBauters C, Baudin E, et al. Prospective endoscopic ultrasonographic evaluation of the frequency of nonfunctioning pancreaticoduodenal endocrine tumors in patients with multiple endocrine neoplasia type 1. Am J Gastroenterol. 2006 Feb;101(2):266-73

17. Goudet P, Murat A, Binquet C, Cardot-Bauters C, Costa A, Ruszniewski P, et al. Risk factors and causes of death in MEN1 disease. A GTE (Groupe d'Etude des Tumeurs Endocrines) cohort study among 758 patients. World J Surg. 2010 Feb;34(2):249-55.

18. Anlauf M, Perren A, Meyer CL, Schmid S, Saremaslani P, Kruse ML, Weihe E, Komminoth P, Heitz PU, Klöppel G. Precursor lesions in patients with multiple endocrine neoplasia type 1-associated duodenal gastrinomas. Gastroenterology. 2005 May;128(5):1187-98.

19. Marini F, Giusti F, Tonelli F, Brandi ML. Management impact: effects on quality of life and prognosis in MEN1. Endocr Relat Cancer. 2017 Oct;24(10): T227-T242.

20. Trouillas J, Labat-Moleur F, Sturm N, Kujas M, Heymann MF, Figarella-Branger D, et al. Pituitary tumors and hyperplasia in multiple endocrine neoplasia type 1 syndrome (MEN1): a case-control study in a series of 77 patients versus 2509 non-MEN1 patients. Am J Surg Pathol. 2008 Apr;32(4):534-43.

21. Ferolla P, Falchetti A, Filosso P, Tomassetti P, Tamburrano G, Avenia N, et al. Thymic neuroendocrine carcinoma (carcinoid) in multiple endocrine neoplasia type 1 syndrome: the Italian series. J Clin Endocrinol Metab. 2005 May;90(5):2603-9.

22. Комиссаренко ИВ, Рыбаков СИ, Кваченюк АН. Классификация злокачественных опухолей надпочечников. Клиническая хирургия. 2004 Сентябрь;(9):25-7 (Komissarenko IV, Rybakov SI, Kvacheniuk AN. Classification of malignant tumors of suprarenal glands. Klin Khir. 2004 Sep;(9):25-7).

23. Кваченюк АМ. Злоякісні пухлини надниркових залоз без ознак гормональної активності. Лікарська справа. 2004 Березень;(2);39-42 (Kvacheniuk AM. Malignant tumors of the adrenal glands without hormonal activity. Lik Sprava. 2004 Mar;(2):39-42).

24. Ye L, Wang W, Ospina NS, Jiang L, Christakis I, Lu J, et al. Clinical features and prognosis of thymic neuroendocrine tumours associated with multiple endocrine neoplasia type 1: A single-centre study, systematic review and meta-analysis. Clin Endocrinol (Oxf) 2017 Dec;87(6):706-16.

25. de Laat JM, van der Luijt RB, Pieterman CR, Oostveen MP, Hermus AR, Dekkers OM, et al. MEN1 redefined, a clinical comparison of mutation-positive and mutation-negative patients. BMC Med. 2016 Nov 15;14(1):182

26. Turner JJ, Christie PT, Pearce SH, Turnpenny PD, Thakker RV Diagnostic challenges due to phenocopies: lessons from Multiple Endocrine Neoplasia type1 (MEN1). Hum Mutat. 2010 Jan;31(1): E1089-101.

27. Giusti F, Marini F, Brandi ML. Multiple Endocrine Neoplasia Type 1. 2005 Aug 31 [Updated 2017 Dec 14]. In: Adam MP, Ardinger HH Pagon RA, et al., editors. GeneReviews® [Internet]. Seattle (WA): University of Washington, Seattle; 1993-2020. Available from: https://www.ncbi.nlm.nih.gov/books/NBK1538/

28. Carroll RW. Multiple endocrine neoplasia type 1 (MEN1). Asia Pac J Clin Oncol. 2013 Dec;9(4):297-309.

29. Anastasopoulou C, Sajja P, Khine K. Multiple Endocrine Neoplasia Type 1 (MEN1) [Internet]. Available from: https://emedicine. medscape.com/article/126438-overview. 
30. Wells SA Jr, Asa SL, Dralle H, Elisei R, Evans DB, Gagel RF, et al. Revised American Thyroid Association guidelines for the management of medullary thyroid carcinoma. Thyroid. 2015 Jun;25(6):567-610.

31. American Society of Clinical Oncology. Multiple Endocrine Neoplasia Type 2 [Internet]. Available from: https://www.cancer.net/cancertypes/multiple-endocrine-neoplasia-type-2.

32. National Comprehensive Cancer Network. NCCN Guidelines: Neuroendocrine and Adrenal Tumors [Internet]. Available from: https:// www.nccn.org/professionals/physician gls/pdf/neuroendocrine.pdf.

33. Raue F, Frank-Raue K. Genotype-phenotype relationship in multiple endocrine neoplasia type 2 . Implications for clinical management. Hormones (Athens). 2009 Jan-Mar;8(1):23-8.

34. Moley JF, Skinner M, Gillanders WE, Lairmore TC, Rowland KJ Traugott AL, et al. Management of the Parathyroid Glands During Preventive Thyroidectomy in Patients With Multiple Endocrine Neoplasia Type 2. Ann Surg. 2015 Oct;262(4):641-6.

35. Kluijfhout WP, van Beek DJ, Verrijn Stuart AA, Lodewijk L, Valk GD, van der Zee DC, et al. Postoperative Complications After Prophylactic Thyroidectomy for Very Young Patients With Multiple Endocrine Neoplasia Type 2: Retrospective Cohort Analysis. Medicine (Baltimore). 2015 Jul;94(29): e1108.

36. Yoshida S, Imai T, Kikumori T, Wada M, Sawaki M, Takada H, et al Long term parathyroid function following total parathyroidectomy with autotransplantation in adult patients with MEN2A. Endocr J. 2009;56(4):545-51.

37. Verrienti A, Carbone A, Bellitti P, Fabiano MC, De Rose RF Maranghi $\mathrm{M}$, et al. A novel double mutation VAL648ILE and VAL804LEU of RET proto-oncogene in multiple endocrine neoplasia type 2. Endocr Pract. 2015 Nov;21(11):1248-54.

38. Zupan A, Glavač D. The development of rapid and accurate screening test for RET hotspot somatic and germline mutations in MEN2 syndromes. Exp Mol Pathol. 2015 Dec;99(3):416-25.

39. National Cancer Institute. Genetics of Endocrine and Neuroendocrine Neoplasias $\left(\mathrm{PDQ}^{\circledR}\right)$-Health Professional Version [Internet]. Available from: https://www.cancer.gov/types/thyroid/hp/medullarythyroid-genetics-pdq\#link/_114_toc.

40. Li Y, Simonds WF. Endocrine neoplasms in familial syndromes of hyperparathyroidism. Endocr Relat Cancer. 2016 Jun;23(6): R229-47.

41. Mathiesen JS, Habra MA, Bassett JHD, Choudhury SM, Balasubramanian SP, Howlett TA, et al. Risk Profile of the RET A883F Germline Mutation: An International Collaborative Study. J Clin Endocrinol Metab. 2017 Jun 1;102(6):2069-74.

42. Pathology and Genetics: Tumours of Endocrine Organs. DeLellis RA, Lloyd RV, Heitz PU, Eng C, editors. World Health Organization Classification of Tumours, Volume 8. Lyon, France: IARC Press; 2004. 359 p. Available from: https://campatho.files.wordpress com/2009/05/who-of-urinary-system-and-male-genital-organs.pdf

43. Castinetti F, Maia AL, Peczkowska M, Barontini M, Hasse-Lazar K, Links TP, et al. The penetrance of MEN2 pheochromocytoma is not only determined by RET mutations. Endocr Relat Cancer. 2017 Aug;24(8): L63-L67.

44. Richards ML, Carter SM, Gross SJ. Multiple endocrine neoplasia type 2 (MEN2) [Internet]. Available from: https://emedicine.medscape. com/article/123447-overview.

45. Neumann HPH, Tsoy U, Bancos I, Amodru V, Walz MK, Tirosh A, et al Comparison of Pheochromocytoma-Specific Morbidity and Mortality Among Adults With Bilateral Pheochromocytomas Undergoing Total Adrenalectomy vs Cortical-Sparing Adrenalectomy. JAMA Netw Open. 2019 Aug 2;2(8): e198898.

46. Lallier M, St-Vil D, Giroux M, Huot C, Gaboury L, Oligny L, et al. Prophylactic thyroidectomy for medullary thyroid carcinoma in gene carriers of MEN2 syndrome. J Pediatr Surg. 1998 Jun;33(6):846-8.

47. van Heurn LW, Schaap C, Sie G, Haagen AA, Gerver WJ, Freling G et al. Predictive DNA testing for multiple endocrine neoplasia 2: a therapeutic challenge of prophylactic thyroidectomy in very young children. J Pediatr Surg. 1999 Apr;34(4):568-71.

48. Thakker RV. Multiple endocrine neoplasia type 1 (MEN1) and type 4 (MEN4). Mol Cell Endocrinol. 2014 Apr 5;386(1-2):2-15.

49. Von Hippel-Lindau Syndrome [Internet]. Available from: https:// www.cancer.net/cancer-types/von-hippel-lindau-syndrome.

50. Krauss T, Ferrara AM, Links TP, Wellner U, Bancos I, Kvachenyuk A et al. Preventive medicine of von Hippel-Lindau disease-associated pancreatic neuroendocrine tumors. Endocr Relat Cancer. 2018 Sep;25(9):783-93.
51. Nordstrom-O'Brien M, van der Luijt RB, van Rooijen E, van den Ouweland AM, Majoor-Krakauer DF, Lolkema MP, etal. Genetic analysis of von Hippel-Lindau disease. Hum Mutat. 2010 May;31(5):521-37.

52. van Leeuwaarde RS, Ahmad S, Links TP, Giles RH. Von HippelLindau Syndrome. 2000 May 17 [updated 2018 Sep 6]. In: Adam MP, Ardinger HH, Pagon RA, Wallace SE, Bean LJH, Stephens K, Amemiya A, editors. GeneReviews ${ }^{\circledR}$ [Internet]. Seattle (WA) University of Washington, Seattle; pp. 1993-2020.

53. Hari Kumar KV, Shaikh A, Sandhu AS, Prusty P. Neurofibromatosis 1 with pheochromocytoma. Indian J Endocrinol Metab. 2011 Oct;15 Suppl 4(Suppl4): S406-8.

54. Porter DE, Prasad V, Foster L, Dall GF, Birch R, Grimer RJ. Survival in Malignant Peripheral Nerve Sheath Tumours: A Comparison between Sporadic and Neurofibromatosis Type 1-Associated Tumours. Sarcoma. 2009;2009:756395.

55. Karagiannis A, Mikhailidis DP, Athyros VG, Harsoulis F. Pheochromocytoma: an update on genetics and management. Endocr Relat Cancer. 2007 Dec;14(4):935-56.

56. Wilding A, Ingham SL, Lalloo F, Clancy T, Huson SM, Moran A, et al. Life expectancy in hereditary cancer predisposing diseases: an observational study. J Med Genet. 2012 Apr;49(4):264-9.

57. Bosco Schamun MB, Correa R, Graffigna P, de Miguel V, Fainstein Day P. Carney complex review: Genetic features. Endocrinol Diabetes Nutr. 2018 Jan;65(1):52-59.

58. Salpea P, Horvath A, London E, Faucz FR, Vetro A, Levy I, et al. Deletions of the PRKAR1A locus at 17q24.2-q24.3 in Carney complex: genotype-phenotype correlations and implications for genetic testing. J Clin Endocrinol Metab. 2014 Jan;99(1): E183-8.

59. Casey M, Vaughan CJ, He J, Hatcher CJ, Winter JM, Weremowicz S, et al. Mutations in the protein kinase A R1alpha regulatory subunit cause familial cardiac myxomas and Carney complex. J Clin Invest. 2000 Sep;106(5): R31-8.

60. Urban C, Weinhäusel A, Fritsch P, Sovinz P, Weinhandl G, Lackner H, et al. Primary pigmented nodular adrenocortical disease (PPNAD) and pituitary adenoma in a boy with sporadic Carney complex due to a novel, de novo paternal PRKAR1A mutation (R96X). J Pediatr Endocrinol Metab. 2007 Feb;20(2):247-52.

61. National Organization for Rare Disorders; Carney complex. Available from: https://rarediseases.org/rare-diseases/carney-complex/.

62. Correa R, Salpea P, Stratakis CA. Carney complex: an update. Eur J Endocrinol. 2015 Oct;173(4): M85-97.

63. Boyce AM, Florenzano P, de Castro LF, Collins MT. Fibrous Dysplasia/ McCune-Albright Syndrome. 2015 Feb 26 [updated 2019 Jun 27] In: Adam MP, Ardinger HH, Pagon RA, Wallace SE, Bean LJH, Stephens K, Amemiya A, editors. GeneReviews ${ }^{\circledR}$ [Internet]. Seattle (WA): University of Washington, Seattle; pp. 1993-2020.

64. Chapurlat RD, Orcel P. Fibrous dysplasia of bone and McCune-Albright syndrome. Best Pract Res Clin Rheumatol. 2008 Mar;22(1):55-69.

65. Dumitrescu CE, Collins MT. McCune-Albright syndrome. Orphanet J Rare Dis. 2008 May 19;3:12.

66. de Sanctis C, Lala R, Matarazzo P, Balsamo A, Bergamaschi R, Cappa M, et al. McCune-Albright syndrome: a longitudinal clinical study of 32 patients. J Pediatr Endocrinol Metab. 1999 NovDec;12(6):817-26.

67. Riminucci M, Robey PG, Bianco P. The pathology of fibrous dysplasia and the McCune-Albright syndrome. Pediatr Endocrinol Rev. 2007 Aug;4 Suppl 4:401-11.

(Надійшла до редакиії 02.10.2020р.)

\section{Орфанные заболевания в эндокринологии}

\section{Н.Д. Тронько, А.Н. Кваченюк, Л.А. Луценко, И.С. Супрун, А.О. Охримчук}

ДУ «Институт эндокринологии и обмена веществ им. В.П. Комиссаренко НАМН Украини»

Резюме. Медико-социальное значение эндокринных орфанных заболеваний обусловлено трудностями в диагностике и лечении, а также неблагоприятным прогнозом и высокой частотой 
Огляди

инвалидизации пациентов с данной патологией. Особенно это относится к таким заболеваниям, как акромегалия и множественная эндокринная неоплазия. В Европе существует специальная программа, которая направлена на решение разнообразных вопросов относительно диагностики, лечения и социального обеспечения пациентов с орфанными заболеваниями. Европейский проект «Орфанет» поддерживается государственными структурами, объединяет информацию относительно редких заболеваний практически во всех европейских странах и включает европейские, интернациональные, национальные и региональные реестры орфанных заболеваний. В Украине опубликован Приказ Министерства здравоохранения Украины от 27.10.2014 г. № 778 «Об утверждении перечня редких (орфанных) заболеваний», которым в Украине официально утверждено 302 нозологии, относящиеся к редким заболеваниям. Среди орфанных заболеваний указано 61 редкую эндокринную болезнь (в том числе расстройства питания и нарушения обмена веществ), а также врожденные пороки развития, хромосомные аномалии и редкие новообразования, в определении тактики ведения которых врач-эндокринолог принимает непосредственное участие. Последнее время увеличивается частота выявления орфанных заболеваний, в том числе и эндокринных. Причиной этого может быть улучшение методов инструментальной и лабораторной диагностики, использование генетических методов диагностики и более широкая информированность врачей разных специальностей относительно ранних проявлений орфанных заболеваний. В Украине проблема орфанных заболеваний длительное время находилась в инертном состоянии. Инициация принятия Национальной стратегии по профилактике, диагностике и лечению редких (орфанных) заболеваний в Украине свидетельствует о признании проблемы на государственном уровне и дает возможность решения вопросов своевременного выявления и лечения редких заболеваний, а так же обеспечения пациентов жизненно необходимыми лекарственными средствами.

Ключевые слова: эндокринные орфанные заболевания, акромегалия, множественная эндокринная неоплазия.

\section{Orphan diseases in endocrinology}

\section{M.D. Tronko, A.M. Kvachenyuk, L.A. Lutsenko, I.S. Suprun, O.O. Ohrimchuk}

SI «V.P. Komisarenko Institute of Endocrinology and Metabolism of the National Academy of Medical Sciences of Ukraine»

Abstract. The medical and social significance of endocrine orphan diseases is due to difficulties in diagnosis and treatment, as well as an unfavorable prognosis and a high incidence of disability in patients with this pathology. This is especially true for diseases such as acromegaly and multiple endocrine neoplasia. In Europe, there is a special program that is aimed at solving a variety of issues regarding the diagnosis, treatment and social security of patients with orphan diseases. The European project «Orphanet» is sup- ported by government agencies, brings together information on rare diseases in almost all European countries including European, international, national and regional registries of orphan diseases. In Ukraine, the Order of the Ministry of Health of Ukraine dated 27.10.2014 № 778 «On approval of the list of rare (orphan) diseases» was published, which in Ukraine officially approved 302 nosologies related to rare diseases. Among the orphan diseases, 61 rare endocrine diseases (including nutritional and metabolic disorders) are indicated, as well as congenital malformations, chromosomal abnormalities and rare neoplasms, in determining the management tactics of which the endocrinologist is directly involved. Recently, the frequency of detecting orphan diseases, including endocrine diseases, has been increasing. The reason for this may be the improvement of the methods of instrumental and laboratory diagnostics, the use of genetic diagnostic methods and a wider awareness of doctors of various specialties regarding the early manifestations of orphan diseases. In Ukraine, the problem of orphan diseases was inactive for a long time. The initiation of the adoption of the National Strategy for the Prevention, Diagnostics and Treatment of Orphan Diseases in Ukraine is the evidence of the recognition of the problem at the state level and makes it possible to resolve issues of timely detection and treatment of rare diseases, as well as to provide patients with vital medicines.

Keywords: endocrine orphan disease, acromegalia, multiple endocrine neoplasia.

Для цитування: Тронько МД, Кваченюк АМ, Луценко ЛА, Супрун ІС, Охрімчук ОО. Орфанні захворювання в ендокринології. Ендокринологія. 2020;25(4):327-342. DOI: 10.31793/1680-1466.2020.25-4.327.

Відомості про авторів: Микола Дмитрович Тронько, д-р мед. наук, проф., чл.-кор. НАН України, акад. НАMH України, ORCID: 0000-0001-7421-0981; Андрій Миколайович Кваченюк д-р мед. наук, проф., ORCID: 0000-0001-6886-3804; Лариса Андріївна Луценко, канд. мед. наук, ORCID: 0000-0001-7587-0324; Ірина Сергіївна Супрун, канд. мед. наук, ORCID: 0000-0003-0761-303X; Олександра Олегівна Охрімчук, лаборант.

Особистий внесок: М.Д. Тронько - керівництво, контроль та рецензування; А.М. Кваченюк - ініціювання розгляду проблеми, участь в обстеженні пацієнтки та в узагальненні результатів обстеження, рецензування; Л.А. Луценко - вивчення літератури за темою, участь в обстеженні пацієнтки та в узагальненні результатів обстеження, аналіз і обробка матеріалу, підготовка до друку; I.C. Супрун - вивчення літератури за темою, аналіз і обробка матеріалу, участь в підготовці до друку; О.О. Охрімчук - участь в підготовці до друку.

Фінансування: стаття підготовлена в рамках бюджетного фінансування Національної академії медичних наук України.

Декларація з етики: автори задекларували відсутність конфлікту інтересів і фінансових зобов'язань. 